\title{
Caesarean scar pregnancy: a 10 case series
}

\author{
Ija Lisovaja ${ }^{1}$ * \\ Department of Gynecology and Obstetrics of Riga Stradins University, 16 Dzirciema Street, Riga, Latvia
}

Received: 26 May 2016

Accepted: 31 May 2016

*Correspondence:

Dr. Ija Lisovaja,

E-mail: ija.lisovaja@yahoo.com

Copyright: ( $\odot$ the author(s), publisher and licensee Medip Academy. This is an open-access article distributed under the terms of the Creative Commons Attribution Non-Commercial License, which permits unrestricted non-commercial use, distribution, and reproduction in any medium, provided the original work is properly cited.

\begin{abstract}
A Caesarean scar pregnancy is challenging and difficult diagnosis that can cause such complications as uterine rupture, profuse haemorrhage and maternal death. There are many single reports in literature but only few case series. Nowadays, caesarean scar pregnancy is becoming more frequent, it is caused by an increasing number of operative deliveries. In this paper, 10 cases of caesarean scar pregnancy treated in the Gynecology Clinic of the Riga Eastern Clinical University Hospital over 6 years are analysed. One of 10 patients had no symptoms on the day of presentation, 4 patients had pain in their lower abdomen, 3 had spotting, 6 had vaginal bleeding, and 2 of them had bleeding after legal abortion. All patients had 1 or 2 caesarean section in their history. Gestational age of the pregnancy was estimated from 3 to 12 weeks by the last menstrual period. All 10 patients were treated surgically. One patient was treated with $75 \mathrm{mg}$ Methotrexate p.o., 2 days course, but the therapy was unsuccessful. Nine of 10 patients had total or subtotal hysterectomy. In one case, excision of scar pregnancy was performed and uterus was preserved. The most common symptoms of caesarean scar pregnancy are pain in the lower abdomen, spotting and vaginal bleeding. The treatment depends on severity of symptoms, gestational age and surgical experience.
\end{abstract}

Keywords: Caesarean scar pregnancy, Ectopic pregnancy, Maternal morbidity

\section{INTRODUCTION}

Ectopic pregnancy is a life-threatening condition that can cause such complications as uterine rupture, massive haemorrhage, hypovolemic shock and maternal death. ${ }^{1}$ Caesarean scar pregnancy is one of the rarest sites of ectopic pregnancy. The first case of caesarean scar ectopic pregnancy was reported in English medical literature in $1978 .^{2}$ The incidence of caesarean scar pregnancy has been estimated to range from 1/1800 $1 / 2500$ of all caesarean deliveries performed. ${ }^{3}$ There is number of scientific papers with case reports. The increasing number of cases and interest can be explained by increasing count of caesarean sections performed nowadays and improved capability to diagnose the condition. ${ }^{4}$
This study presents 10 cases of caesarean scar pregnancy treated over 6 years in the Gynaecology Clinic of the Riga East Clinical University Hospital.

\section{CASE REPORT}

This is a retrospective case series of 10 patients in between 3 and 12 postmenstrual weeks with diagnosed caesarean scar pregnancy who were referred to the Gynaecology Clinic of the Riga East Clinical University Hospital for diagnosis and treatment between 2010 and 2015. The diagnosis was confirmed by transvaginal ultrasound examination. All patients underwent surgical treatment. Clinical data and findings are presented in the Table 1. 
Table 1: Characteristics of the ten patients with pregnancy located in a uterine scar.

\begin{tabular}{|c|c|c|c|c|c|c|c|c|c|c|}
\hline $\begin{array}{l}\text { Maternal } \\
\text { age } \\
\text { (years) }\end{array}$ & $\begin{array}{l}\text { Presenting } \\
\text { symptoms }\end{array}$ & $\begin{array}{l}\text { Diagnosis at } \\
\text { the day of } \\
\text { admission }\end{array}$ & $\begin{array}{l}\text { Gestational } \\
\text { age in } \\
\text { weeks (by } \\
\text { LMP) }\end{array}$ & $\begin{array}{l}\text { Gestational } \\
\text { age in } \\
\text { weeks (by } \\
\text { USG) }\end{array}$ & $\begin{array}{l}\text { No. of } \\
\text { section } \\
\text { caesarea }\end{array}$ & $\begin{array}{l}\text { No. of } \\
\text { abortions }\end{array}$ & $\begin{array}{l}\text { Gynecological } \\
\text { history }\end{array}$ & Treatment & $\begin{array}{l}\text { b-hCG IU/l } \\
\text { pretreatment }\end{array}$ & $\begin{array}{l}\text { Days in } \\
\text { hospital }\end{array}$ \\
\hline 38 & $\begin{array}{l}\text { Spastic pain in } \\
\text { lower abdomen }\end{array}$ & $\begin{array}{l}\text { Graviditas } \\
\text { extrauterina }\end{array}$ & 5 & $4+4$ & $\begin{array}{l}1 \text { (foetus } \\
\text { magnus) }\end{array}$ & 3 & $\begin{array}{l}\text { Polypus } \\
\text { endometrii, } \\
\text { Syphilis. }\end{array}$ & $\begin{array}{l}\text { Diagnostic } \\
\text { laparoscopy at the } \\
\text { day of admission. } \\
\text { Laparatomia modo } \\
\text { Pfannenstiel, } \\
\text { hysterectomia } \\
\text { subtotalis sine } \\
\text { adnexibus on } 3^{\text {rd }} \text { day. }\end{array}$ & 6974 & 8 \\
\hline 30 & $\begin{array}{l}\text { Spotting and pain } \\
\text { in lower abdomen }\end{array}$ & $\begin{array}{l}\text { Graviditas in } \\
\text { sept. } 6+3 \\
\text { progressiva. } \\
\text { Abortus } \\
\text { incipiens. } \\
\text { Haematoma } \\
\text { tertochoriale }\end{array}$ & 7 & $\begin{array}{l}6+3, \text { fetal } \\
\text { heart activity } \\
+\end{array}$ & 2 & 1 & $\begin{array}{l}\text { Cystis ovarii } \\
\text { dextra }\end{array}$ & $\begin{array}{l}\text { Laparatomia modo } \\
\text { Pfannenstiel. } \\
\text { Evacuatio ovii } \\
\text { exregio cicatricis } \\
\text { uteris. Suturae uteri } \\
\text { on } 6^{\text {th }} \text { day. }\end{array}$ & 614,16 & 12 \\
\hline 22 & $\begin{array}{l}\text { Vaginal bleeding, } \\
\text { spotting } 1 \text { month }\end{array}$ & $\begin{array}{l}\text { Metrorrhagia. } \\
\text { Graviditas in } \\
\text { loci cicatricis } \\
\text { uteri susp. }\end{array}$ & - & - & $\begin{array}{l}1 \text { (breech } \\
\text { presentatio) }\end{array}$ & 1 & - & $\begin{array}{l}\text { Laparatomia modo } \\
\text { Pfannenstiel, } \\
\text { extirpatio uteri on } \\
\text { 2nd day. }\end{array}$ & 48,08 & 5 \\
\hline 31 & Vaginal bleeding & $\begin{array}{l}\text { Graviditas } \\
\text { extrauterina }\end{array}$ & 5 & $\begin{array}{l}7+1, \text { fetal } \\
\text { heart activity } \\
+\end{array}$ & $\begin{array}{l}1 \text { (intra } \\
\text { uterine } \\
\text { hypoxia) }\end{array}$ & 1 & - & $\begin{array}{l}\text { Laparatomia modo } \\
\text { Pfannenstiel, } \\
\text { hysterectomia totalis } \\
\text { cum adnexibus } \\
\text { dextra on } 2^{\text {nd }} \text { day. }\end{array}$ & - & 8 \\
\hline 28 & $\begin{array}{l}\text { Profuse vaginal } \\
\text { bleeding during } \\
\text { legal abortion, } \\
\text { TA } 90 / 30 \mathrm{mmHg}\end{array}$ & $\begin{array}{l}\text { Graviditas in } \\
\text { loci cicatricis } \\
\text { uteri. HIV. } \\
\text { HCV. }\end{array}$ & - & - & 1 & 1 & - & $\begin{array}{l}\text { Laparatomia modo } \\
\text { Pfannenstiel, } \\
\text { hysterectomia totalis } \\
\text { cum salpinx } \\
\text { bilateralis on } 1^{\mathrm{st}} \text { day. }\end{array}$ & - & 8 \\
\hline 23 & none & $\begin{array}{l}\text { Graviditas } \\
\text { cervicalis susp. } \\
\text { Graviditas in } \\
\text { loci cicatricis } \\
\text { uteri susp. }\end{array}$ & 3 & - & 2 & 1 & - & $\begin{array}{l}\text { Methotrexate } 75 \mathrm{mg} \\
2 \text { days p.o., } \\
\text { Laparatomia modo } \\
\text { Pfannenstiel, } \\
\text { amputatio uteri on }\end{array}$ & 8800,35 & 28 \\
\hline
\end{tabular}




\begin{tabular}{|c|c|c|c|c|c|c|c|c|c|c|}
\hline & & & & & & & & 19th day. & & \\
\hline 33 & $\begin{array}{l}\text { Vaginal bleeding } \\
\text { and pain in lower } \\
\text { abdomen }\end{array}$ & $\begin{array}{l}\text { Graviditas in } \\
\text { loci cicatricis } \\
\text { uteri }\end{array}$ & 5 & - & 2 & 1 & - & $\begin{array}{l}\text { Laparatomia modo } \\
\text { Pfannenstiel, } \\
\text { extirpatio uteri cum } \\
\text { salpingis bilateralis } \\
\text { on } 1^{\text {st }} \text { day }\end{array}$ & 22741 & 5 \\
\hline 41 & $\begin{array}{l}\text { Vaginal bleeding } \\
\text { after legal } \\
\text { abortion } 2 \text { weeks } \\
\text { ago. }\end{array}$ & $\begin{array}{l}\text { Haematoma } \\
\text { loca cicatricis }\end{array}$ & - & - & 2 & 0 & - & $\begin{array}{l}\text { Laparatomia modo } \\
\text { Pfannenstiel, } \\
\text { amputatio uteri sine } \\
\text { adnexibus on 4th } \\
\text { day. }\end{array}$ & 3885 & 11 \\
\hline 38 & Spotting & $\begin{array}{l}\text { Graviditas in } \\
\text { sept. } 7 / 8 \\
\text { progressiva. } \\
\text { Abortus } \\
\text { incipiens. } \\
\text { Insertio } \\
\text { graviditas } \\
\text { cicatricis } \\
\text { S.Caesarea }\end{array}$ & 8 & $\begin{array}{l}7+6, \text { fetal } \\
\text { heart activity } \\
+\end{array}$ & 2 & 2 & $\begin{array}{l}2 \mathrm{x} \text { foetus } \\
\text { mortus }\end{array}$ & $\begin{array}{l}\text { Laparatomia } \\
\text { mediana inferior, } \\
\text { amputatio uteri sine } \\
\text { adnexibus on } 1^{\text {st }} \text { day. }\end{array}$ & - & 4 \\
\hline 37 & $\begin{array}{l}\text { Vaginal bleeding } \\
\text { and pain in lower } \\
\text { abdomen }\end{array}$ & $\begin{array}{l}\text { Graviditas in } \\
\text { sept. } 12 / 13 \text {. } \\
\text { Abortus } \\
\text { incompletus }\end{array}$ & 12 & - & 1 & 3 & - & $\begin{array}{l}\text { Abrasio cavi uteri on } \\
1^{\text {st }} \text { day. on } 2 \text { nd day. }\end{array}$ & 526 & 7 \\
\hline
\end{tabular}


Over 6 years, there were 10 patients with confirmed caesarean scar pregnancy in our gynaecological department. The maternal age was from 22 to 41 years. One of 10 patients had no symptoms at the day of presentation, 4 patients had pain in their lower abdomen, 3 had spotting, 6 had vaginal bleeding, and 2 of them had bleeding after legal abortion. One Patient was urgently hospitalized after attempt to curettage caesarean scar area pregnancy ambulatory. She had profuse vaginal bleeding and hypotension 90/30 $\mathrm{mmHg}$.

In five cases the diagnosis - caesarean scar pregnancy was mentioned at the first examination in the emergency room. In two cases ectopic pregnancies were suspected. In two cases progressing miscarriage and in one case incomplete miscarriage were suspected.

Gestational age of pregnancy was estimated to be from 3 to 12 weeks by the last menstrual period. It was 4 patients' ultrasonography report in medical records. Estimated gestational age by USG was from 4 to 7 weeks; 3 of 4 embryos had cardiac activity. Five patients had 1 section caesarean and five patients - 2 in their history. Almost all patients, except one, had abortions in their history. One patient had two foetus mortus in her history.

All 10 patients were treated surgically. One patient underwent diagnostic laparoscopy on the day of admission because ectopic pregnancy was suspected and one patient had curettage on the first day of admission because incomplete miscarriage was suspected. One patient was treated with $75 \mathrm{mg}$ Methotrexate (MTX) p.o., 2 days course. At the beginning, beta HCG started to decrease but then continued to stay high and surgery was performed on $19^{\text {th }}$ day of stay in hospital. Nine of 10 patients had total or subtotal hysterectomy. In one case excision of scar pregnancy was performed and uterus was preserved. On the day of admission, levels of beta-human chorionic gonadotropin (b-hCG) ranged from 48.08 to 22 $741 \mathrm{IU} / \mathrm{L}$. Average stay in hospital was 9 days, ranged from 4 to 28 days.

\section{DISCUSSION}

The most common symptoms of caesarean scar pregnancy are pain in the lower abdomen, spotting and vaginal bleeding. In this case series one patient was asymptomatic. The condition often is misdiagnosed as cervical pregnancies, spontaneous abortions in progress, ectopic pregnancy, or low intrauterine pregnancies. ${ }^{3,4}$ Five patients were diagnosed correctly on the day of admission. Ultrasonography is helpful for diagnosing pregnancy implantation into the Caesarean section scar. The following criteria should be met: (1) empty uterine cavity; (2) gestational sac located anteriorly at the level of the internal os covering the visible or presumed site of the previous caesarean section scar of the lower uterine segment; (3) evidence of functional trophoblastic/placental circulation on Doppler examination; (4) negative 'sliding organs sign' which is negative when the gestational sac cannot be displaced from its position at the level of the internal os using gentle pressure applied by the transvaginal probe. ${ }^{5}$ The diagnosis can be confirmed by magnetic resonance imaging (MRI) or during laparoscopy and/or laparotomy. ${ }^{6}$

The diagnosis should be established as soon as possible to reduce the risk of major complications, such as uterine rupture, massive haemorrhage and maternal death. ${ }^{7}$

It is mentioned in the literature that up to $72 \%$ of caesarean scar pregnancies occur in women who have had 2 or more caesarean deliveries. ${ }^{8}$ In this study, half women had 2 caesarean deliveries in history, and half had only one.

There are two possible tactics to manage caesarean scar pregnancy: conservative and operative. Conservative treatment can include: dilatation and curettage, excision of trophoblastic tissues (laparotomy or laparoscopy), local and/or systemic administration of methotrexate, bilateral hypogastric artery ligation associated with trophoblastic evacuation, and selective uterine artery embolization combined with curettage and/or MTX administration. ${ }^{9}$ In this case series, two patients was treated conservatively. One patient received systematic MTX. The unsuccessful outcome of treatment can be explained by scar histological structure. Such pregnancy is surrounded by fibrous scar rather than by normally vascularized myometrium. Therefore, systemic absorption of local MTX is minute. This also may potentially limit the systemic absorption of the drug and delay complete resorption of the pregnancy. ${ }^{10}$ One patient was treated successfully by laparotomy and excision of trophoblastic tissues. There are no guidelines how to manage that kind of ectopic pregnancy. Each particular case is unique. Information about treatment and possible outcomes should be provided to patient.

\section{CONCLUSIONS}

Early diagnostics, early treatment and experience are essential to prevent maternal morbidity and mortality. The most common symptoms of caesarean scar pregnancy are pain in the lower abdomen, spotting and vaginal bleeding. Early diagnostics is possible in case of early recognition of ultrasound findings. The incidence of caesarean scar pregnancy is increasing due to increase in caesarean section rates.

\section{Funding: No funding sources \\ Conflict of interest: None declared \\ Ethical approval: Not required}

\section{REFERENCES}

1. Cignini P, Giorlandino M, Caserta L, Dominici L, Giorlandino C. The importance of early diagnosis in 
caesarean scar pregnancy. J Perinat Med. 2007;1(2):29-31.

2. Ash A, Smith A, Maxwell D. Caesarean scar pregnancy. BJOG. 2007;114:253-63.

3. Timor-Tritsch IE, Monteagudo A, Santos R, Tsymbal T, Pineda G, Arslan A. The diagnosis, treatment, and follow-up of cesarean scar pregnancy. Am J Obstet Gynecol. 2012;207:44.e1-13.

4. Natasha G, Haas B, Ekechukwu K, Blankstein J. Cesarean scar ectopic pregnancy. J Clin Gynecol Obstet. 2013;2(1):42-4.

5. Jurkovic D, Hillaby K, Woelfer B, Lawrence A, Salim R and Elson CJ. First-trimester diagnosis and management of pregnancies implanted into the lower uterine segment Cesarean section scar. Ultrasound Obstet Gynecol. 2003;21:220-7.

6. Aich R, Solanki N, Kakadiya K, Bansal A, Joshi M, Nawale A. Ectopic pregnancy in caesarean section scar: a case report. Radiology Case Reports. 2015;10:68-71.

7. Tulpin L, Morel O, Malartic C, Barranger E. Conservative management of a Cesarean scar ectopic pregnancy: a case report. Cases Journal. 2009;2:7794.

8. Osborn DA, Williams TR, Craig BM. Cesarean Scar Pregnancy. Sonographic and magnetic resonance imaging findings, complications, and treatment. J Ultrasound Med. 2012;31:1449-56.

9. Fadhlaoui A, Khrouf M, Kh'emiri K, Nouira K, Chaker A, Zhioua F. Successful conservative treatment of a cesarean scar pregnancy with systemically administered methotrexate and subsequent dilatation and curettage: a case report. Case Rep Obstet Gynecol. 2012;248564:1-6.

10. Maymon R, Halperin R, Mendlovic S, Schneider D, Vaknin Z, Herman A, Pansky M. Ectopic pregnancies in caesarean section scars: the 8 year experience of one medical center. Human Reproduction. 2004;19(2):278-84.

11. Ouyang Y, Li X, Yi Y, Gong F, Lin G, Lu G. Firsttrimester diagnosis and management of cesarean scar pregnancies after in vitro fertilization-embryo transfer: a retrospective clinical analysis of 12 cases. Reprod Biol Endocrinol. 2015;13:126.

Cite this article as: Lisovaja I. Caesarean scar pregnancy: a 10 case series. Int J Reprod Contracept Obstet Gynecol 2016;5:2413-7. 